University of Nebraska - Lincoln

DigitalCommons@University of Nebraska - Lincoln

2005

\title{
A Multilocus Population Genetic Survey of the Greater Sage- Grouse Across their Range
}

\section{S. J. Oyler-Mccance}

Rocky Mountain Center for Conservation Genetics and Systematics, Department of Biological Sciences, University of Denver, Denver, CO

S.E. Taylor

Rocky Mountain Center for Conservation Genetics and Systematics, Department of Biological Sciences, University of Denver, Denver, CO

T. W. Quinn

Rocky Mountain Center for Conservation Genetics and Systematics, Department of Biological Sciences, University of Denver, Denver, CO

Follow this and additional works at: https://digitalcommons.unl.edu/usgsstaffpub

Part of the Earth Sciences Commons

Oyler-Mccance, S. J.; Taylor, S.E.; and Quinn, T. W., "A Multilocus Population Genetic Survey of the Greater Sage-Grouse Across their Range" (2005). USGS Staff -- Published Research. 43.

https://digitalcommons.unl.edu/usgsstaffpub/43

This Article is brought to you for free and open access by the US Geological Survey at DigitalCommons@University of Nebraska - Lincoln. It has been accepted for inclusion in USGS Staff -- Published Research by an authorized administrator of DigitalCommons@University of Nebraska - Lincoln. 


\title{
A multilocus population genetic survey of the greater sage-grouse across their range
}

\author{
S. J. OYLER-MCCANCE, ${ }^{*}$ S. E. TAYLORt and T. W. QUINNt \\ *U.S. Geological Survey, Fort Collins Science Center, 2150 Centre Ave, Building C, Fort Collins, CO 80526 USA, +Rocky Mountain \\ Center for Conservation Genetics and Systematics, Department of Biological Sciences, University of Denver, Denver, CO 80208 USA
}

\begin{abstract}
The distribution and abundance of the greater sage-grouse (Centrocercus urophasianus) have declined dramatically, and as a result the species has become the focus of conservation efforts. We conducted a range-wide genetic survey of the species which included 46 populations and over $\mathbf{1 0 0 0}$ individuals using both mitochondrial sequence data and data from seven nuclear microsatellites. Nested clade and STRUCTURE analyses revealed that, in general, the greater sage-grouse populations follow an isolation-by-distance model of restricted gene flow. This suggests that movements of the greater sage-grouse are typically among neighbouring populations and not across the species, range. This may have important implications if management is considering translocations as they should involve neighbouring rather than distant populations to preserve any effects of local adaptation. We identified two populations in Washington with low levels of genetic variation that reflect severe habitat loss and dramatic population decline. Managers of these populations may consider augmentation from geographically close populations. One population (Lyon/ Mono) on the southwestern edge of the species' range appears to have been isolated from all other greater sage-grouse populations. This population is sufficiently genetically distinct that it warrants protection and management as a separate unit. The genetic data presented here, in conjunction with large-scale demographic and habitat data, will provide an integrated approach to conservation efforts for the greater sage-grouse.

Keywords: gene flow, genetic diversity, greater sage-grouse, microsatellites, mtDNA, nested clade analysis
\end{abstract}

Received 20 September 2004; revision received 29 October 2004; accepted 12 January 2005

\section{Introduction}

The range of the greater sage-grouse (Centrocercus urophasianus) historically spanned 12 western US states and three Canadian provinces (Schroeder et al. 2004), yet this species currently occupies only $56 \%$ of its historic (pre-European period) range (Fig. 1) with extirpations in at least one state and one province (Connelly \& Braun 1997; Schroeder et al. 2004). Regional population declines have been dramatic, ranging from $17 \%$ to $47 \%$ (Connelly \& Braun 1997). These declines are likely linked to the loss, fragmentation, and degradation of sagebrush (Artemisia spp.) habitat (Braun 1998), resulting in the isolation of small populations from larger populations existing in more contiguous habitat (Fig. 1). Consequently, the greater sage-grouse have

Correspondence: Sara J. Oyler-McCance, Fax: 303-871-3471; E-mail: sara_oyler-mccance@usgs.gov become a species of conservation concern and petitions have been filed to list them for protection under the US Endangered Species Act.

Management of the greater sage-grouse has previously been based on information from studies of demographic rates and habitat requirements that have focused on local populations (reviewed in Connelly et al. 2000). The distribution of genetic variation among populations across the entire range of the greater sage-grouse has been unknown despite increasing pressure on managers to make difficult decisions about which populations may be more 'important' than others. The identification of any genetically discrete groups of the greater sage-grouse is paramount to the development of greater sage-grouse management plans. In addition, faced with an increasingly fragmented distribution with small and isolated populations, it is important to determine the relative amount of genetic diversity contained in each population. Populations with relatively low 


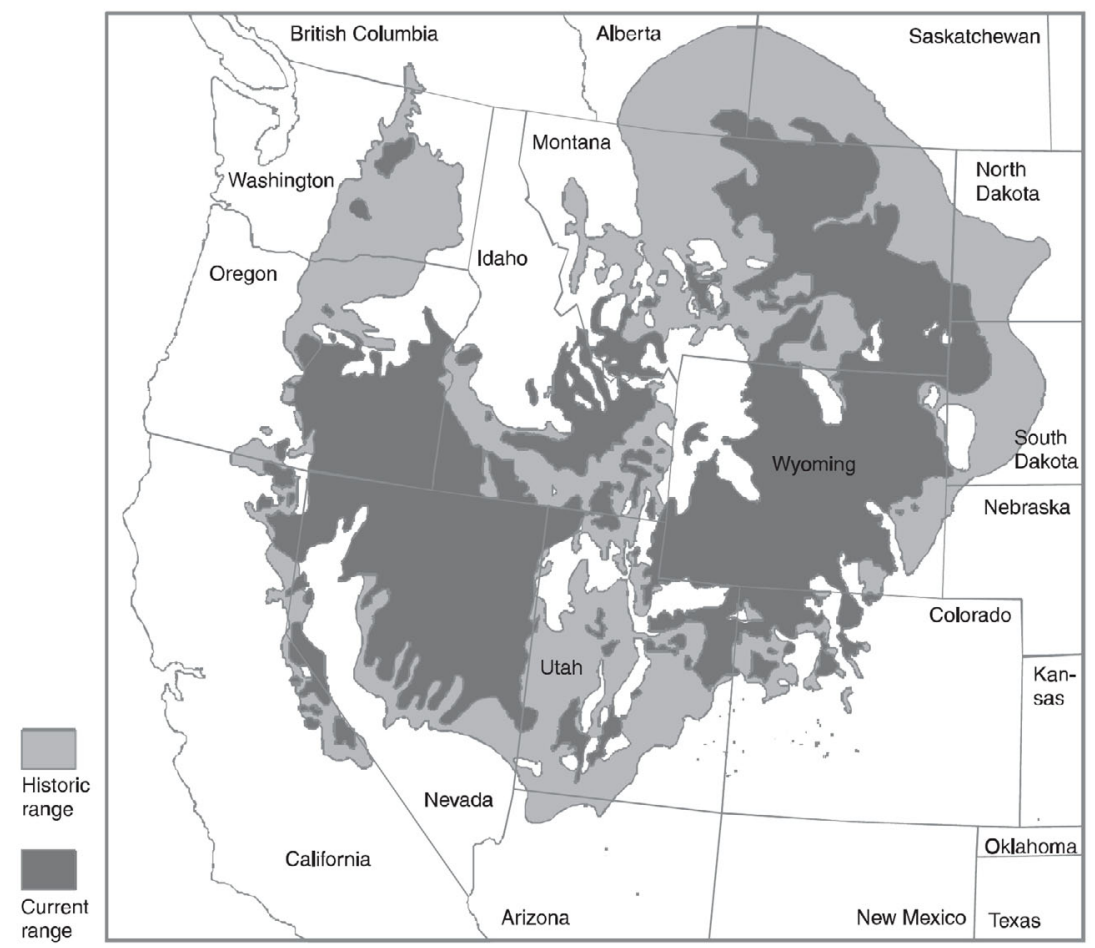

Fig. 1 Historic and current distribution of the greater sage-grouse (from Schroeder et al. 2004).

levels of genetic diversity can suffer from inbreeding effects and can be more susceptible to parasitic agents and disease. Genetic data can provide information relevant to an understanding of gene flow, isolation, genetic diversity, and the evolutionary history of a species. Further, it can facilitate a cohesive management strategy that takes genetic distinctiveness into account, based in part on a clear picture of the entire 'genetic landscape' of a species. This increases the efficiency of management decisions and adds to their scientific foundation.

Previous population genetic studies of sage-grouse have focused on assessing taxonomic status. Kahn et al. (1999) and Oyler-McCance et al. (1999) used mitochondrial and nuclear markers to document the genetic distinctiveness of sage-grouse in southwestern Colorado. This, combined with morphological (Hupp \& Braun 1991) and behavioural (Young et al. 1994) information led to the recognition of a new species of sage-grouse (Young et al. 2000), the Gunnison sage-grouse (Centrocercus minimus). Benedict et al. (2003) investigated whether or not genetic data supported a subspecific taxonomic delineation in the western part of the greater sage-grouse range that had long been questioned. These studies provided useful taxonomic information and knowledge of the distribution of genetic variation locally, yet they lacked the range-wide perspective necessary to make management decisions regarding the greater sage-grouse at the species level. Here we greatly extend the sampling range and density of previous studies to provide a comprehensive examination of the distribution of genetic variation across the entire range of the greater sage-grouse using both mitochondrial DNA (mtDNA) sequence data and data from nuclear microsatellites.

\section{Materials and methods}

\section{Tissue collection and DNA extraction}

Forty-six populations from all US states with populations of the greater sage-grouse (11) and one Canadian province (Alberta) were included in this study. The Owyhee, Oregon population was included solely in the microsatellite analysis and the Converse, Wyoming population was only included in the mtDNA analysis. We collected approximately 20 samples per population. Blood samples were collected from the Alberta, Lyon/Mono, South Dakota, Strawberry Valley, and Yakima populations. Feather samples were collected from the Douglass/Grant population. For all other populations, including most samples from Lyon/ Mono and South Dakota, muscle tissue was obtained from the wings of hunter-killed birds. As in Benedict et al. (2003), most population names correspond to hunt units. DNA was extracted from most samples using either a phenol-chloroform method (Kahn et al. 1999) or the Wizard Genomic DNA Purification System (Promega) following the manufacturer's instructions. Some blood samples were later re-extracted using the GenomicPrep Blood DNA Isolation Kit (Amersham Biosciences) using the modifications of Oyler-McCance et al. (in press). 


\section{Mitochondrial sequencing}

A 146-base pair portion of hypervariable control region I was amplified using polymerase chain reaction (PCR) and sequenced using a dye terminator cycle sequencing reaction (Beckman Coulter CEQ8000) as described by Benedict $e t$ al. (2003). This region was used because it was known to contain approximately $92 \%$ of the variable sites in a larger 380-base pair region spanning control region I (Kahn et al. 1999).

\section{Microsatellite fragment analysis}

Seven nuclear microsatellite loci (LLST1, SGCA5, SGCA9, SGCA11, LLSD3, LLSD8, and ADL0230) were screened using the methods described in Oyler-McCance et al. (in press). Briefly, PCRs were performed using a dye-labelled forward primer and amplified products were then run on the CEQ 8000 Genetic Analysis System (Beckman Coulter).

\section{Data analysis}

All mtDNA sequences were edited and aligned using SEQUENCHER version 4.1.4 and haplotypes were identified using programs MACDNASIS PRO version 2.0 (Hitachi) and GENETOOL. Maximum-parsimony analysis of all haplotypes was conducted using PAUP* version 4.1 (Swofford 2003). Blue grouse (Dendragapus obscurus) was used as an outgroup because it has been confirmed by molecular work (Ellsworth et al. 1996; Lucchini et al. 2001) to be the closest extant relative to sage-grouse. An heuristic analysis was conducted keeping best trees only, with maxtrees set at 100 . The starting tree was obtained by stepwise addition with swapping on the best tree when multiple starting trees exist. The addition sequence was simple, with the outgroup used as the reference taxon. Five hundred trees were held at each step. Branch swapping was carried out with the treebisection-reconnection (TBR) algorithm, saving multiple trees and swapping on the best trees only. This analysis was followed by an heuristic bootstrap analyis using the default settings but with 1000 replicates. We used nested clade analysis (NCA) to differentiate patterns of population history and gene flow. This was performed by generating an unrooted haplotype cladogram using the statistical parsimony software TCS version 1.13 (Clement et al. 2000). The cladogram was constructed following the algorithm of Templeton et al. (1992) with ambiguities resolved following Crandall \& Templeton (1993) and Crandall et al. (1994). The resulting cladogram was then nested using procedures from Templeton et al. (1987) and input along with geographical coordinates of all populations in the software program GEODIS version 2.2 (Posada et al. 2000). The program GEODIs calculates the clade distance $\left(D_{c}\right)$, nested clade distance $\left(D_{n}\right)$, and the average interior distances minus the average tip distances $(I-T)_{c}$ and $(I-T)_{n}$. These four statistics were used in conjunction with the key provided by Templeton (1998) and subsequently updated in Templeton (2004) to examine if the observed clade structure provided information about biological processes such as restricted gene flow, allopatric fragmentation, or long-distance migration events.

We calculated the total number of microsatellite alleles per locus and the mean number of alleles for each population. Microsatellite loci were tested (by population) for departures from Hardy-Weinberg equilibrium (HWE) (Guo \& Thompson 1992) using the computer program ARLEQUIN 2.001 (Schneider et al. 2001). A test for linkage disequilibrium (LD) among pairs of loci within each population was performed using GENEPOP (http://wbiomed.curtin.edu.au/ genepop/) on the Web (Markov chain parameters: 5000 dememorization steps, 500 batches, 5000 iterations per batch) (Raymond \& Rousset 1995).

Pairwise population genetic distances $\left(R_{\mathrm{ST}}\right.$, Slatkin 1995) were calculated in ARLEQUIN (Schneider et al. 2001). The $R_{\mathrm{ST}}$ values were used to construct a neighbour-joining (NJ) tree using PHYLIP 3.57 (Felsenstein 1989) that was viewed using TREEVIEW 1.6.6 (Page 1996).

$R_{\mathrm{ST}}$ values were used to perform an analysis of molecular variance (AMOVA) (Excoffier et al. 1992) in ARLEQUIN. AMOVA partitions the molecular variance (microsatellite allele size) into three categories: between groups, among populations, and among individuals within populations. We tested for population bottlenecks using the software BOTTLENECK (Cornuet \& Luikart 1997) and the Wilcoxon test under the TPM model with 1000 replications. Population structure was also examined using stRUCTURE 2.00 software (Pritchard et al. 2000). In this program, individuals were grouped into clusters without regard to the assigned population using a model-based clustering analysis. The number of 'populations' $(K)$ was initially estimated by conducting five independent runs each of $K=1-45$ with 100000 Markov chain Monte Carlo (MCMC) repetitions and a 100000 burn-in period using the model with admixture, correlated allele frequencies, and no prior information. An additional set of five independent runs was then conducted with $K=5-15$ with 500000 MCMC repetitions and a 500000 burn-in period using the above model. A Mantel (1967) test was used to look for a correlation between genetic distance and geographical distance using the software ZT (Bonnet \& Van de Peer 2002).

\section{Results}

\section{Mitochondrial analysis}

We sequenced a portion of the mitochondrial control region I in 614 individuals, adding to the 466 individuals that had been sequenced previously (Kahn et al. 1999; Benedict et al. 2003). Of the 1080 total individuals sequenced over the course of this study and our previous work, 80 unique 
1296 S. J. OYLER-MCCANCE, S. E. TAYLOR and T. W. QUINN

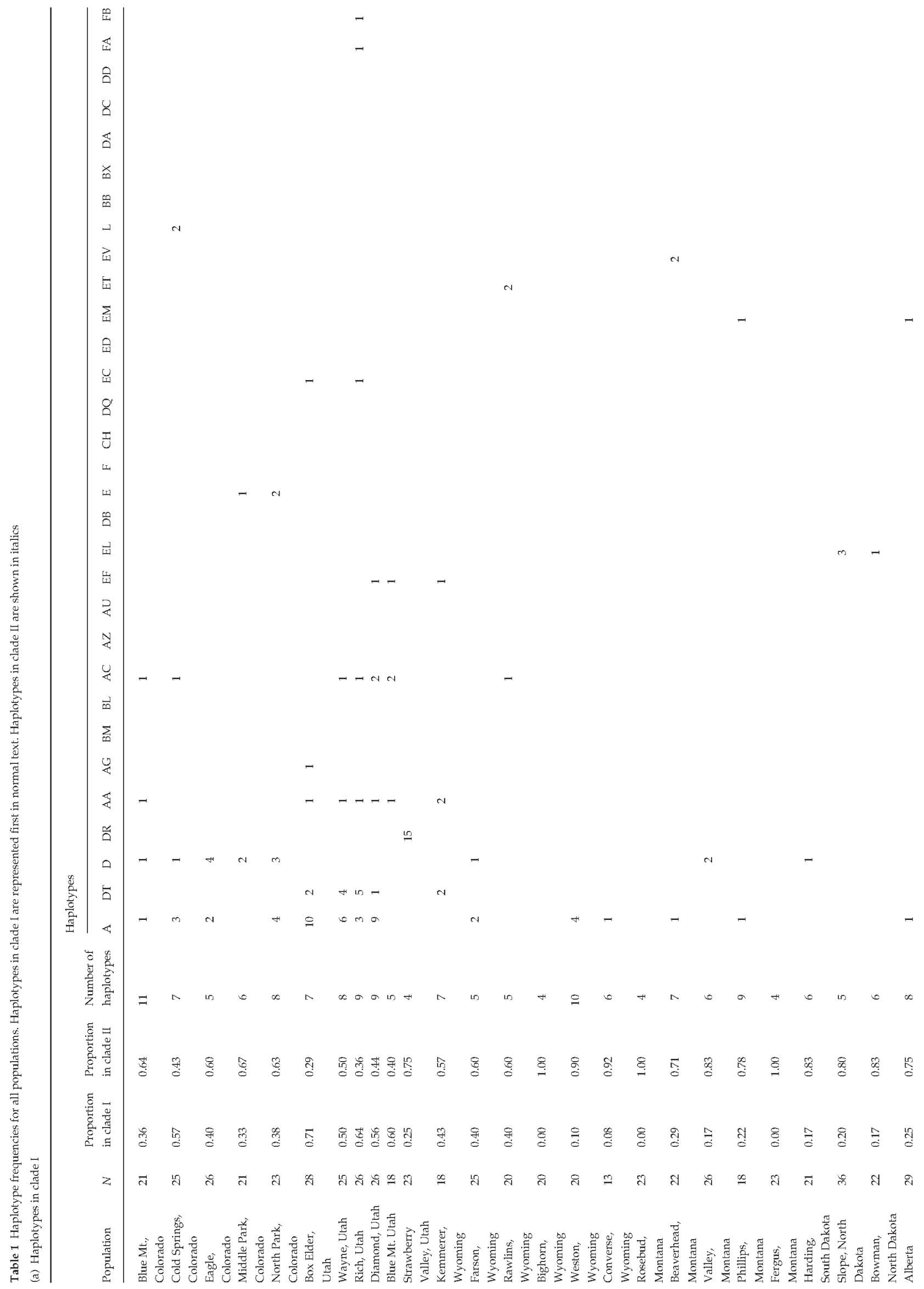


POPULATION GENETICS OF THE GREATER SAGE-GROUSE 1297

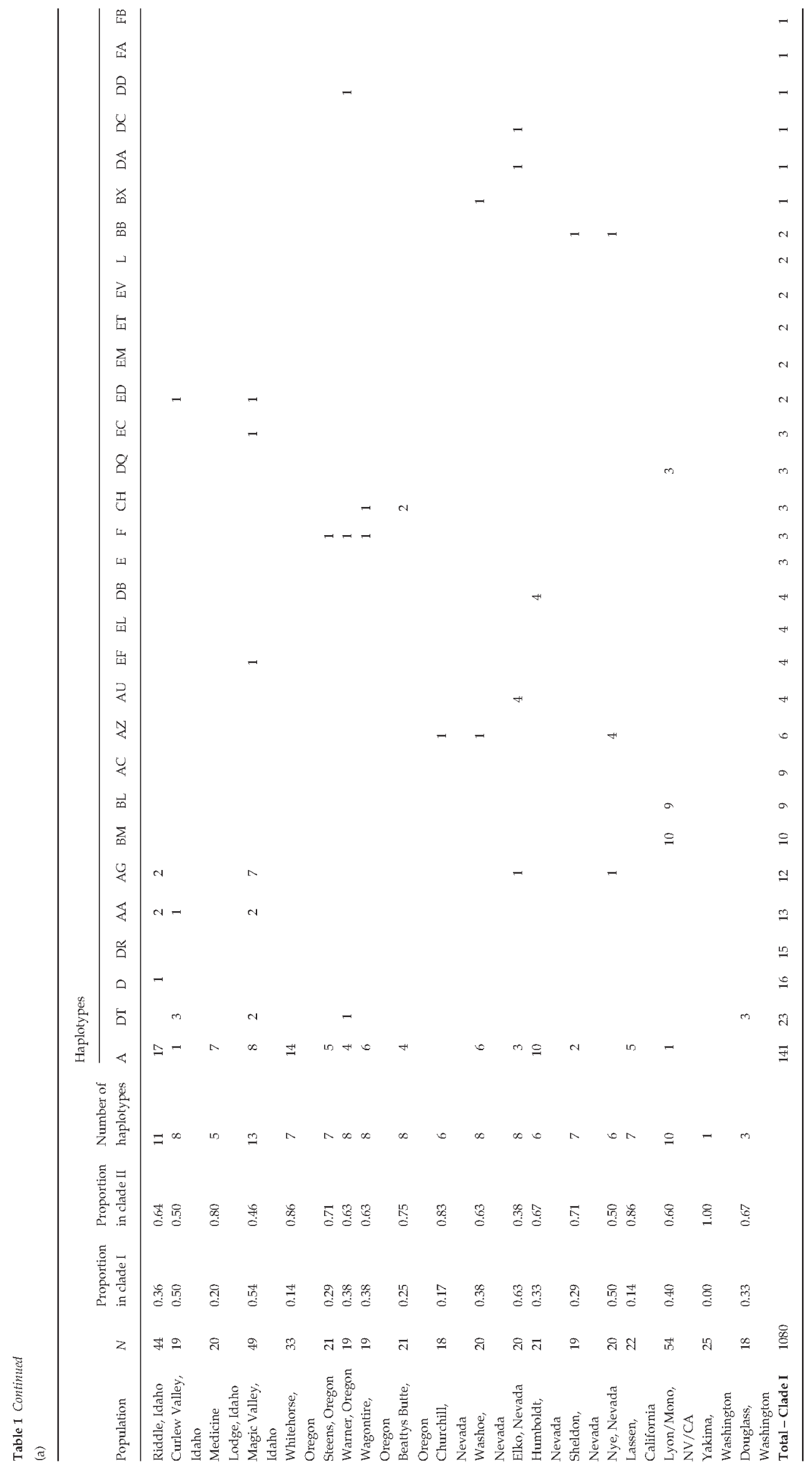


1298 S. J. OYLER-MCCANCE, S. E. TAYLOR and T. W. QUINN

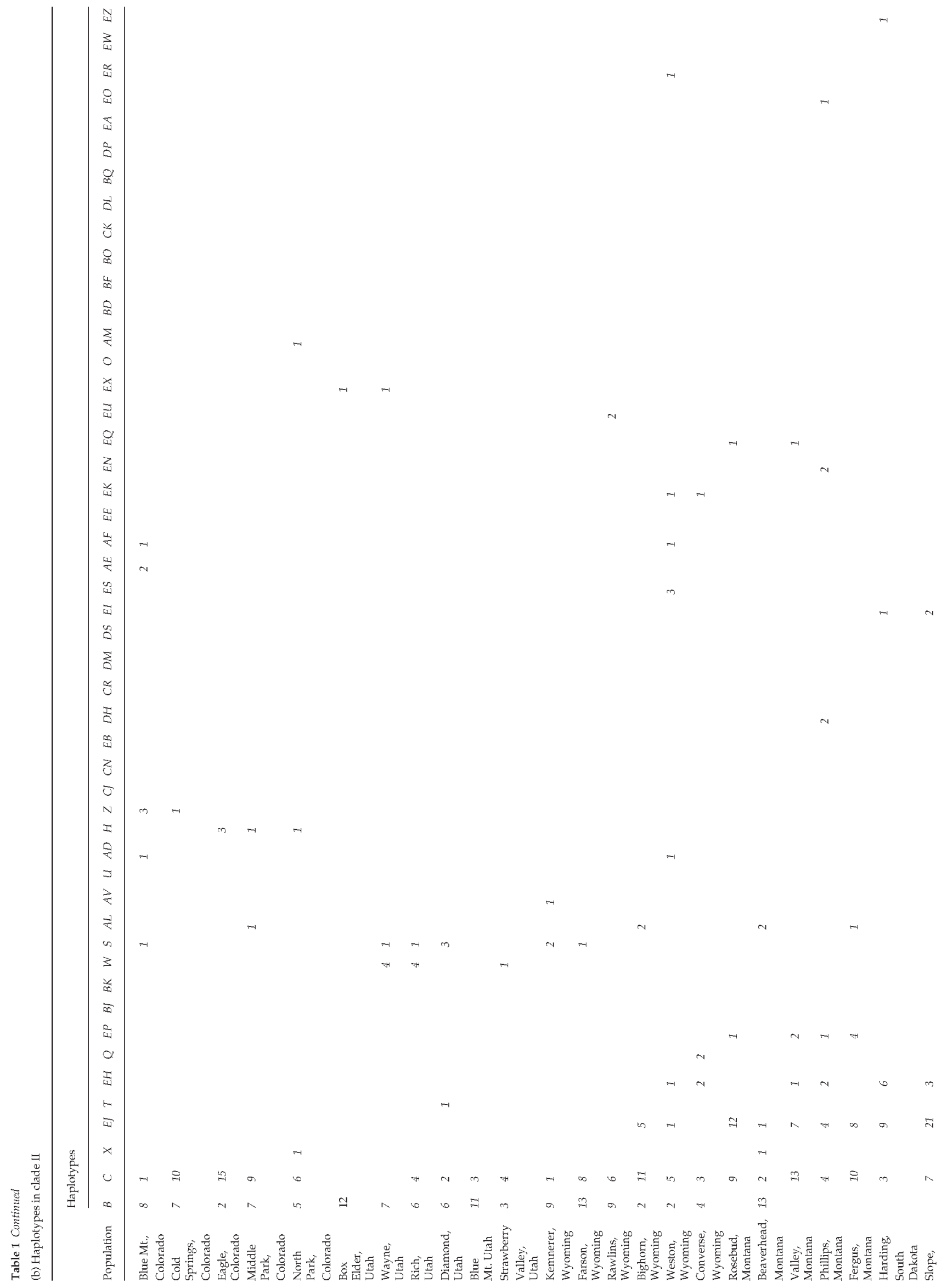


POPULATION GENETICS OF THE GREATER SAGE-GROUSE 1299

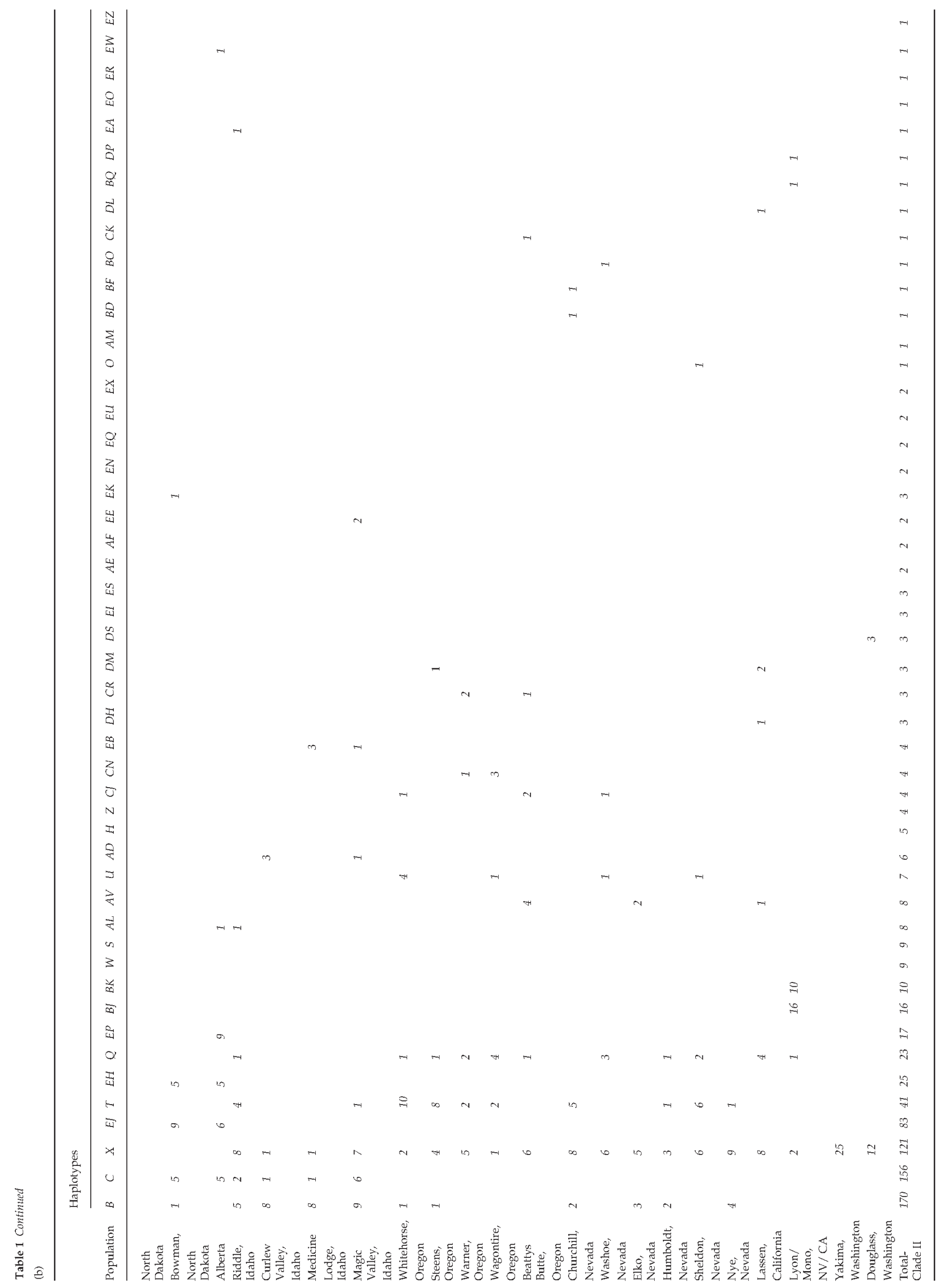




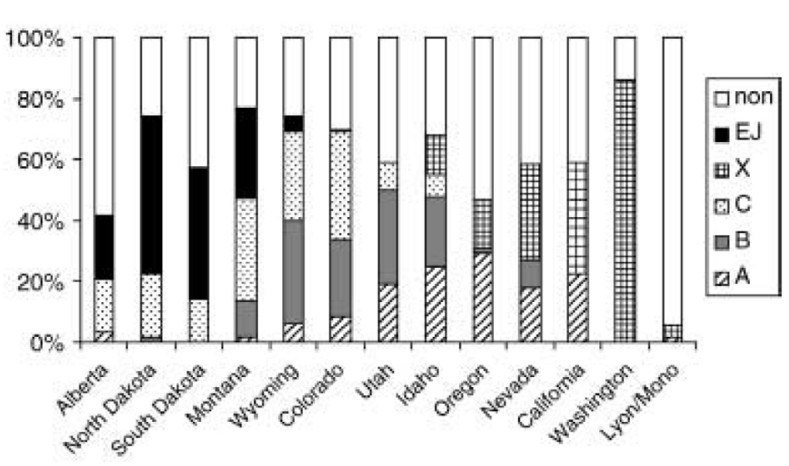

Fig. 2 Proportion of individuals in each state with common haplotypes (non represents haplotypes that are not common). The haplotypes EJ, X, C, B, and A were the most common haplotypes found in the study. Each bar represents the proportion of each of these common haplotypes for every state.

mtDNA haplotypes were identified (Table 1). Of these 80 haplotypes, 28 are newly described here (Accession nos AY850036-AY850062, and AY846747). Parsimony analysis distributed all haplotypes into one of two distinct monophyletic clades (31 in clade I, 49 in clade II). Of the 100 trees of shortest length (124 steps) that were retained, all maintained monophyly of those two clades. Bootstrap support was $91 \%$ for clade I and $88 \%$ for clade II. The maximum DNA sequence difference between the two clades was $18.4 \%$ and the minimum difference between any greater sage-grouse haplotype and the outgroup sequence was $23.4 \%$. Along the 146-base pair sequence, 60 sites were variable with 39 transitions, 18 transversions, and 8 insertions/deletions. Five of those sites were both transitions and transversions.

The average number of haplotypes per population was 6.9 with a high of 13 haplotypes in Magic Valley and a low of one in Yakima (Table 1). Five haplotypes (A, B, C, X, and
EJ) were common and widespread representing $62 \%$ of all individuals sequenced. Haplotype A was found virtually everywhere with the exception of Washington, North and South Dakota, and parts of Wyoming and Montana. (Fig. 2). Haplotype B was present in most populations except in areas of Montana, South Dakota, Oregon, California, and Washington while haplotype $\mathrm{C}$ was widespread except in Oregon, Nevada, California, and Washington (Fig. 2). Haplotype $X$ was more localized spanning Idaho, Oregon, Nevada, California, and Washington as was haplotype EJ, which is found primarily in Wyoming, Montana, North and South Dakota, and Alberta (Fig. 2). The Lyon/ Mono population (Fig. 2) has an extremely low percentage of individuals with common haplotypes (5\%). Of the 54 individuals from the Lyon/Mono population, 50 are characterized by haplotypes unique to that population.

In the NCA, statistical parsimony revealed five separate networks, three that were composed of only one haplotype (haplotypes CJ, BX, or DC). The two networks that represented the remaining 77 haplotypes corresponded to the two distinct clades described previously (Kahn et al. 1999; Benedict et al. 2003). The 95\% plausible set of both networks was comprised of many haplotypes and each contained several ambiguous connections that were resolved using the frequency and topology criterion. The two networks were nested resulting in a final network (Fig. 3). Because the three other networks contained only one haplotype per network, they were not used in subsequent analyses.

We rejected the null hypothesis of no relationship between the mitochondrial haplotype genealogy and the geographical distribution of haplotypes for 29 of the 39 clades in the analysis (Table 2). Eighteen of those 29 clades were uninformative, categorized variously as inconclusive, insufficient genetic resolution, or inadequate genetic sampling (Table 2) using the updated key by Templeton (2004). Eleven clades,

Table 2 Characteristics of each clade described using nested clade analysis

\begin{tabular}{|c|c|c|c|c|c|c|}
\hline $\begin{array}{l}\text { Continuous range } \\
\text { expansion }\end{array}$ & $\begin{array}{l}\text { Allopatric } \\
\text { fragmentation }\end{array}$ & $\begin{array}{l}\text { Restricted gene } \\
\text { flow with } \\
\text { isolation by distance }\end{array}$ & $\begin{array}{l}\text { Inadequate } \\
\text { geographic } \\
\text { sampling }\end{array}$ & $\begin{array}{l}\text { Insufficient genetic } \\
\text { resolution }\end{array}$ & Inconclusive & No relationship \\
\hline $2-3$ & $1-3$ & $1-5$ & $1-1$ & $1-9$ & $1-18$ & $1-2$ \\
\hline \multirow[t]{12}{*}{$2-4$} & $1-8$ & $1-13$ & $1-4$ & $1-22$ & $1-19$ & $1-11$ \\
\hline & & $1-20$ & & $1-32$ & $1-30$ & $1-14$ \\
\hline & & $2-1$ & & & $1-31$ & $1-15$ \\
\hline & & $2-8$ & & & $2-6$ & $1-25$ \\
\hline & & $3-4$ & & & $2-7$ & $1-26$ \\
\hline & & $3-5$ & & & $2-9$ & $1-27$ \\
\hline & & & & & $2-11$ & $2-2$ \\
\hline & & & & & $2-13$ & $2-10$ \\
\hline & & & & & $3-1$ & $3-3$ \\
\hline & & & & & $3-2$ & \\
\hline & & & & & $4-1$ & \\
\hline & & & & & $4-2$ & \\
\hline
\end{tabular}



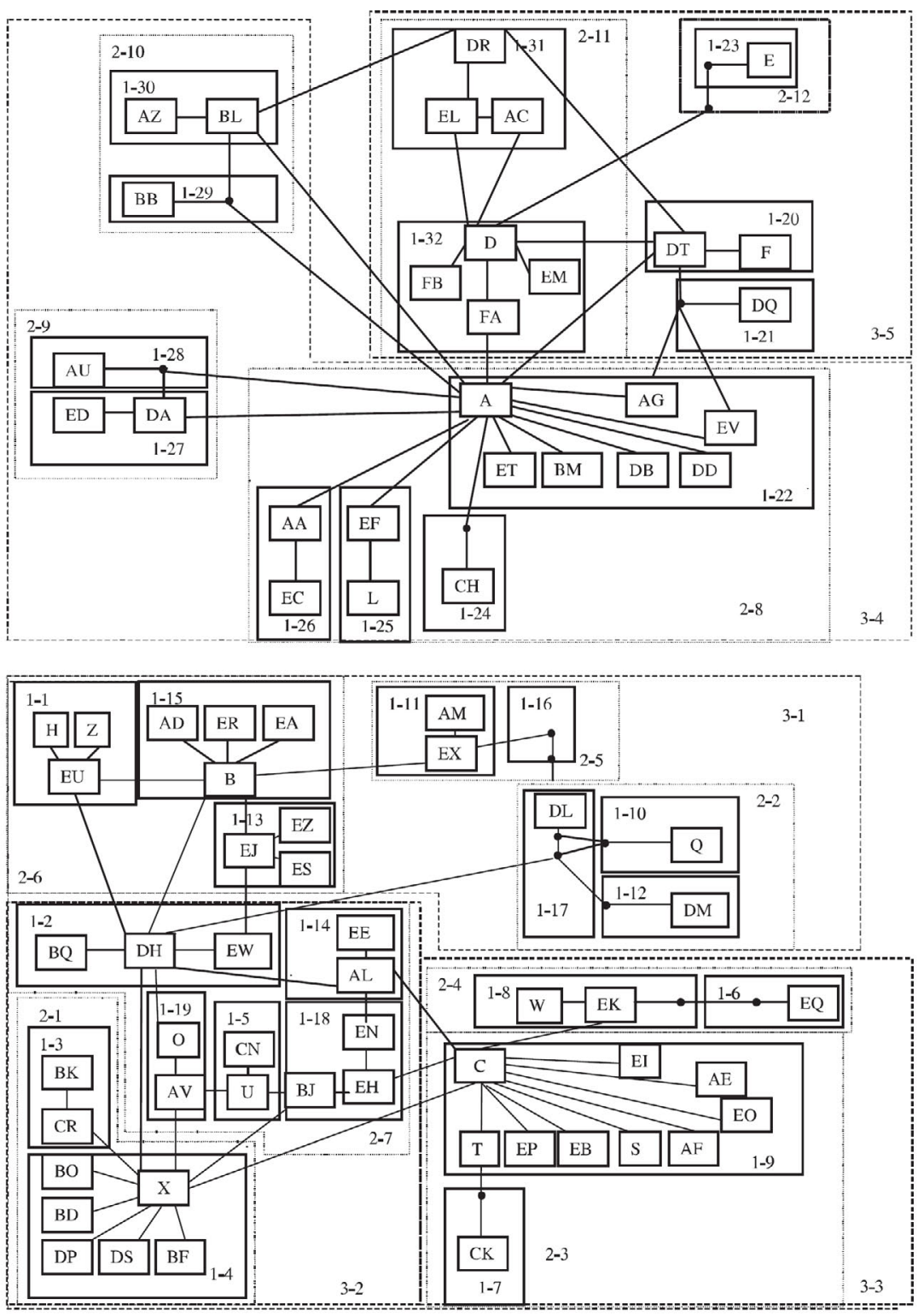

Fig. 3 Unrooted estimated 95\% parsimony cladogram of 80 haplotyopes detected in the greater sage-grouse. Haplotypes are represented by letters. Lines represent single mutational events, dots represent intermediate haplotypes not found in our sample but necessary to link haplotypes that were found. Numbers represent the level of nesting in the analysis. Most haplotypes fell into one of two distinct clades (previously described by Kahn et al. 1999 and Benedict et al. 2003). The placement for connection of these two clades could not be determined so they are represented separately as clade I (top) and clade II (bottom). Three haplotypes could not be connected with confidence to either clade or each other and thus are not included here. however, did provide insight into the biogeographical history of the greater sage-grouse. Clades 2-3 and 2-4 were characterized as continuous range expansion and two clades (1-3 and 1-8) represented patterns associated with allopatric fragmentation. The pattern of restricted gene flow with isolation by distance was the most prominent being characterized by seven clades (1-5, 1-13, 1-20, 2-1, 2-8, 3-4, and 3-5).

\section{Microsatellite analysis}

The number of microsatellite alleles per locus across all populations ranged from five (LLST1) to 31 (SGCA9). The mean number of alleles per population across all seven loci ranged from 3.1 alleles in Douglass/Grant to 7.1 alleles in Alberta (Table 3). One population, Strawberry Valley, was shown to have undergone a recent population bottleneck $(P=0.0078)$. There were 27 significant departures from HWE $(P<0.05)$ among the 315 possible combinations of population and loci. Because of the large number of combinations (multiple tests), it is possible that some departures were caused by chance. To correct for multiple tests, the $P$ value was lowered to 0.00016 (Bonferroni method) and only one population/locus comparison was significant $(P<0.00016)$. The significant departure was in the Eagle population at the SGCA9 locus. The test for LD examined each pair of loci in each population for a total of 945 possible comparisons. Using the Bonferroni correction, the $P$ value was 
1302 S. J. OYLER-MCCANCE, S. E. TAYLOR and T. W. QUINN

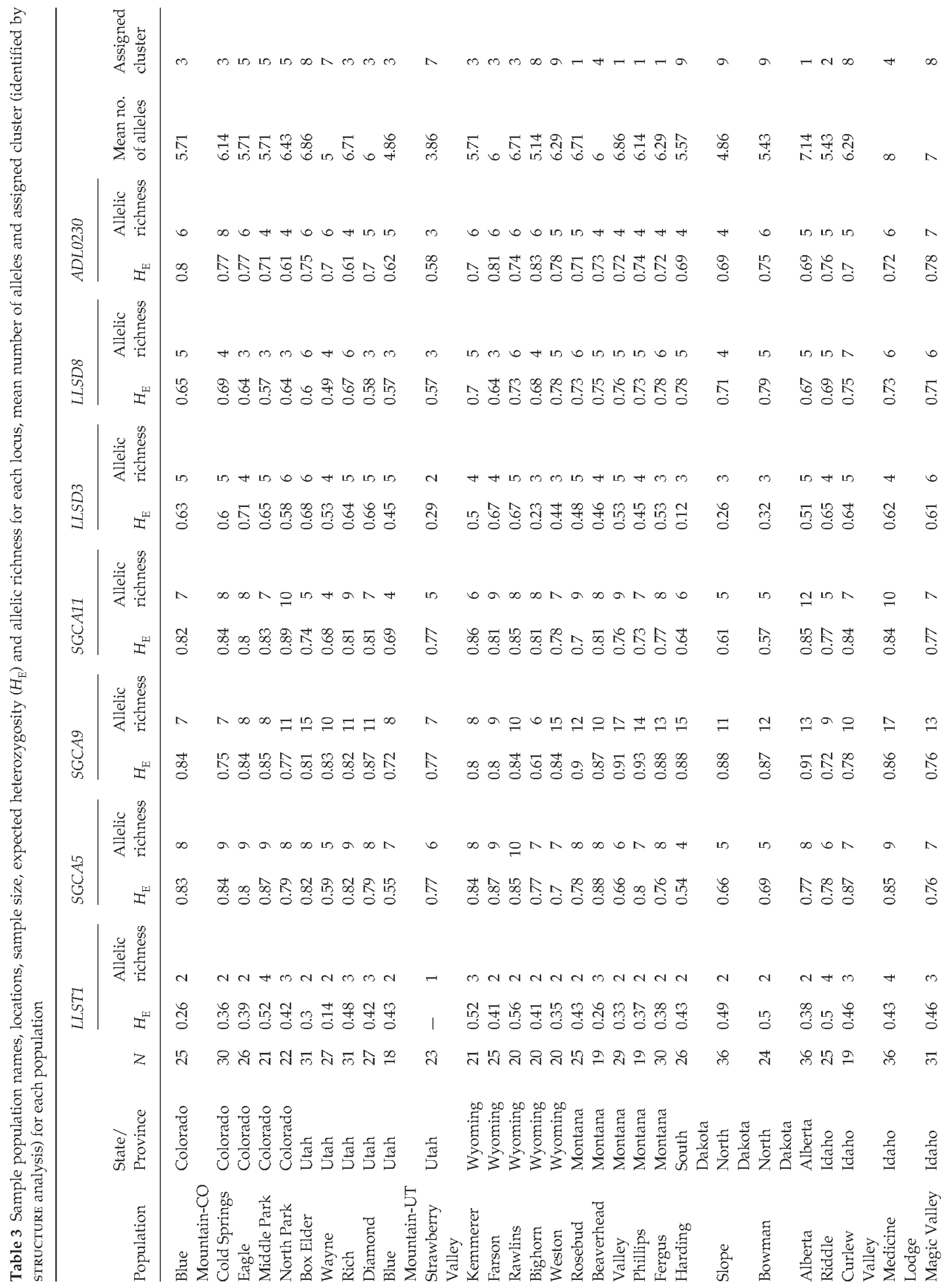


POPULATION GENETICS OF THE GREATER SAGE-GROUSE 1303

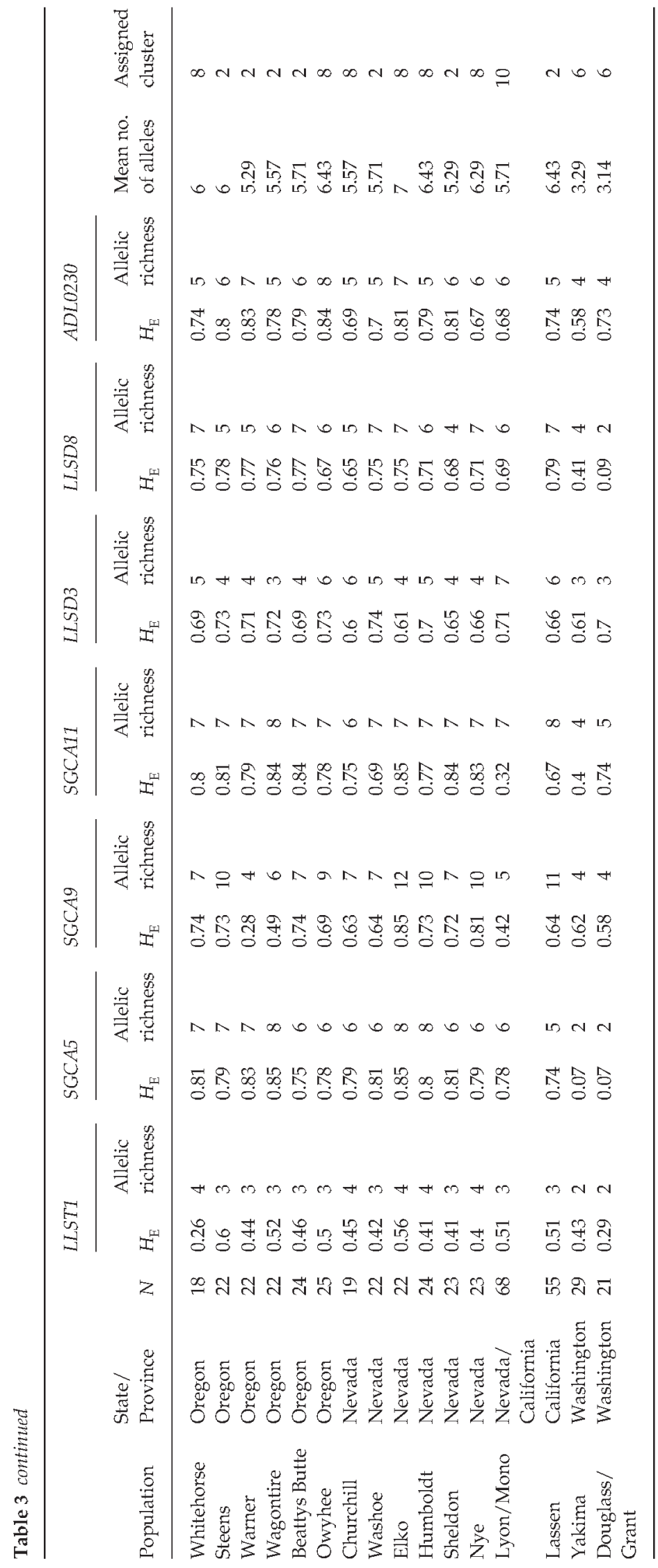




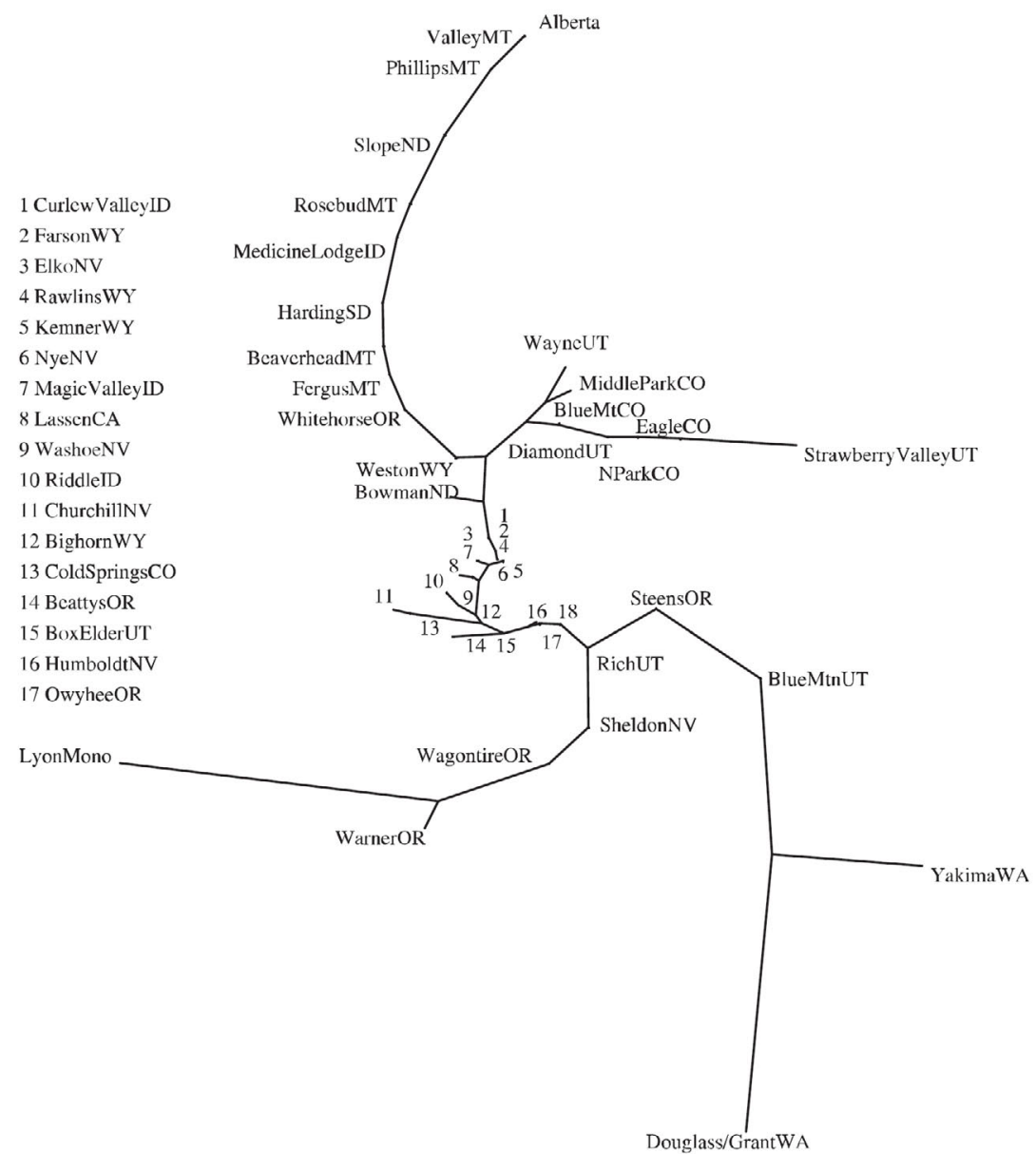

Fig. 4 Neighbour-join tree constructed using the genetic distance $R_{\mathrm{ST}}$ for 45 populations of the greater sage-grouse. Population names are represented followed by a two-letter abbreviation of the corresponding state. Samples from the Canadian province Alberta are labelled Alberta. The Lyon/Mono population, which spans the border of Nevada and California, is labelled LyonMono. lowered to 0.00005 . There was only one significant comparison, the SGCA9 and SGCA11 loci in the Eagle population.

Of the 990 population pairwise $\left(R_{\mathrm{ST}}\right)$ genetic distances, 194 were significant $(P=0.00005$, Bonferroni corrected). Most notably, the Lyon/Mono population was significantly different from all other populations except Steens, Wagontire, Warner, Sheldon, and Box Elder. The Douglass/Grant, Yakima, and Alberta populations differed significantly from 27, 32, and 25 other populations, respectively.

The $R_{\mathrm{ST}}$ genetic distance tree also indicated that the Douglass/Grant and Yakima populations and the Lyon/ Mono population were genetically distant from each other and from all other populations (Fig. 4). When the population groups suggested by the $R_{\mathrm{ST}}$ values (Douglass/Grant and Yakima, Lyon/Mono, Alberta) were tested against all other populations and each other (four total groups), the AMova based on the $R_{\mathrm{ST}}$ distances revealed that most of the variation in the two categories of interest was explained by the among groups (9.93\%) category, rather than the among populations within groups category $(6.71 \%)$ (Table $4 a)$.

STRUCTURE assigned each individual a probability of belonging to each of 10 clusters. Each population was assigned to the appropriate cluster based on the largest number of individuals with a certain cluster assignment (Table 3, Fig. 5). The number of populations assigned to clusters ranged from 1 (Lyon/Mono, cluster 10) to 10 (various populations from Nevada, Idaho, Wyoming, Utah, and Oregon, cluster 8 ). $R_{\mathrm{ST}}$ genetic distances were recalculated based on the STRUCTURE clusters. An AMOVA based on the 10 clusters indicated that, relative to the Amova based on four groups (Table $4 \mathrm{a}$ ), the proportion of among-group variation remained nearly the same $(8.91 \%)$ while the among-populations-within-groups variation was reduced (1.86\%) (Table 4b). The Mantel test revealed that there was a positive correlation between genetic distance and geographical distance ( $r=0.4312, P=0.00001)$ (Fig. 6).

\section{Discussion}

The 80 mtDNA haplotypes fell into one of two monophyletic clades as described by Kahn et al. (1999) and Benedict et al. (2003). The two clades are not separated geographically. In fact, all but four populations contain individuals with haplotypes from both clades. Kahn et al. (1999) and Benedict et al. (2003) have previously argued that these two clades may have resulted from the 
Table 4 Analysis of molecular variance using seven microsatellite loci

(a) Forty-five populations, four groups. Group 1, Lyon/Mono; group 2, Alberta; group 3, Douglass/Grant, Yakima; group 4, all other populations

\begin{tabular}{lcccc}
\hline Source of variation & d.f. & Sum of squares & Variance components & Percentage of variation \\
\hline Among groups & 3 & 5712 & 7.53 & 9.93 \\
Among populations within groups & 41 & 13024.15 & 5.06 & 6.71 \\
Within populations & 2317 & 146534.18 & 63.24 & 83.36 \\
\hline
\end{tabular}

(b) Forty-five populations, 10 groups. Groups are the 10 clusters identified in the structurE analysis (see Table 3)

\begin{tabular}{lrrrr}
\hline Source of variation & d.f. & Sum of squares & Variance components & Percentage of variation \\
\hline Among groups & 9 & 14229.92 & 6.32 & 8.91 \\
Among populations within groups & 35 & 4506.23 & 1.32 & 1.86 \\
Within populations & 2317 & 146534.18 & 63.24 & 89.23 \\
\hline
\end{tabular}

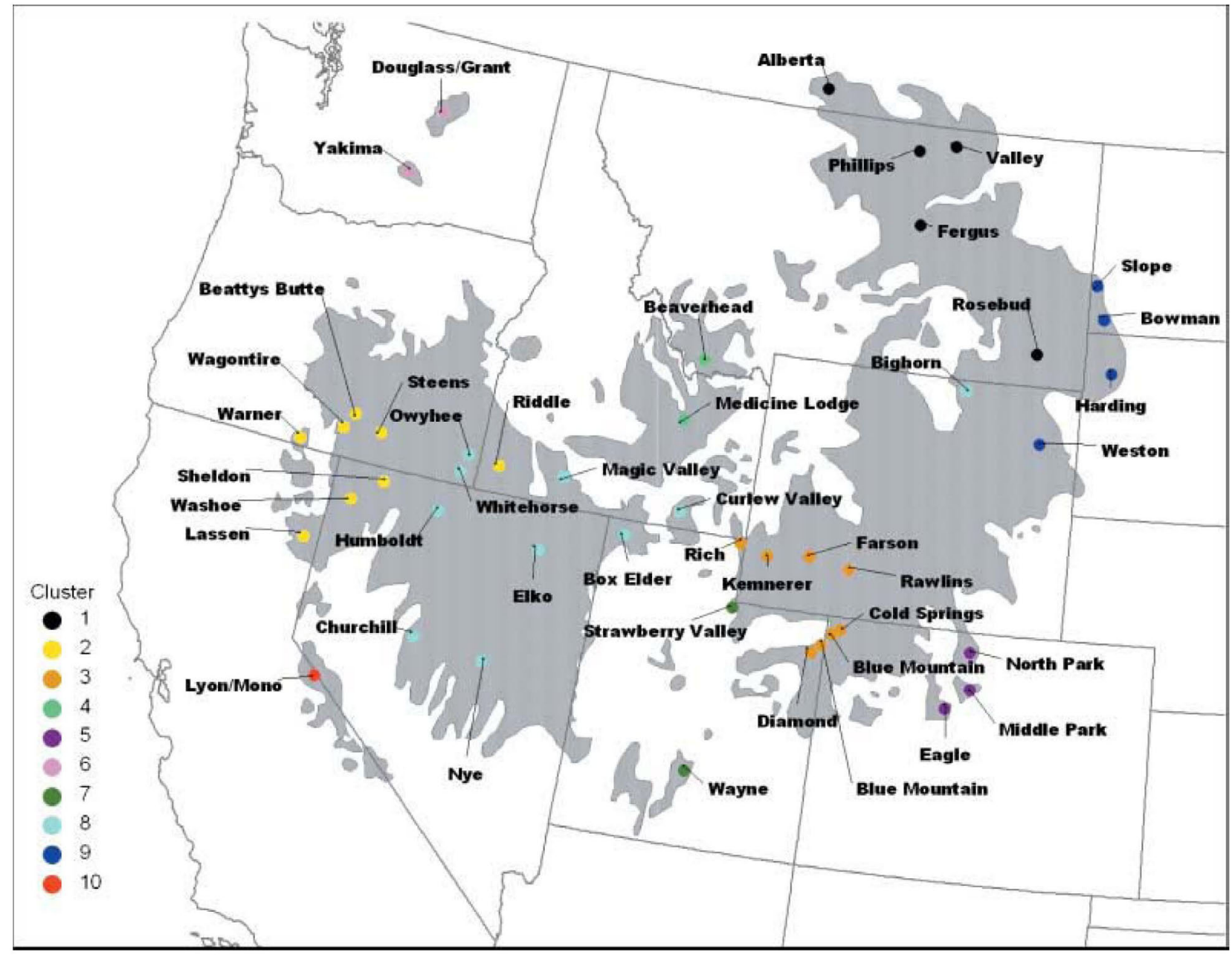

Fig. 5 Map of sampling sites for the microsatellite analysis colour coded by the cluster each population has been assigned to using STRUCTURE analysis.

separation of sage-grouse into two allopatric groups approximately $850000 \mathrm{BP}$, perhaps in association with the patchy distribution of sagebrush habitat during the Pleistocene epoch.
In each population the percentage of individuals in each clade shifted across the range with many populations in the north (particularly the northeast) containing few or no haplotypes from clade I (Table 1). This may suggest a 


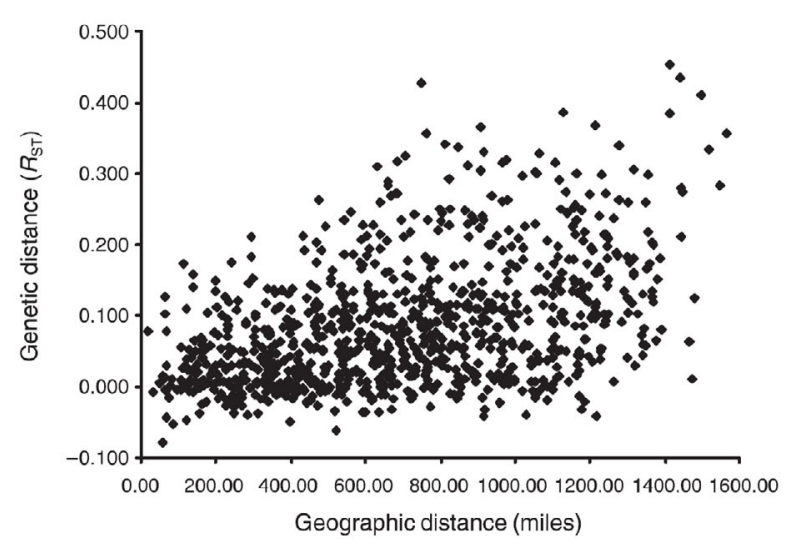

Fig. 6 Relationship between the genetic distance $R_{\mathrm{ST}}$ and geographical distance for all pairs of populations of the greater sage-grouse.

range expansion to the north and northeast following the Pleistocene epoch. Fossil records have documented sage-grouse during the Pleistocene in the south-central and southeastern part of their current range (Shufeldt 1913; Howard \& Miller 1933; Howard 1952; Miller 1963, 1965; McDonald \& Anderson 1975; Grayson 1976; Emslie 1985, 2004; Emslie \& Heaton 1987) and more recently (6000 вP) in western portions of the range (Miller 1963; Grayson 1976), yet sage-grouse have not been recorded during this period in the northern part of their current range.

Results from our NCA suggest continuous range expansion in two of our nested clades (2-3 and 2-4). Populations in clade 2-3 are found throughout most of the range, yet populations in clade 2-4 occur only in the central and northeastern part of the range, in Utah, Wyoming, Montana, and North Dakota. More recent evidence suggests that the range expansion, particularly in the northeast, has continued to present day. Schroeder et al. (2004) provided a pre-European period distribution of the greater sagegrouse that they developed by examining early written observations of sage-grouse. Although some ambiguities exist, they propose that the distribution of sage-grouse was following a northward and eastward transition into areas not originally occupied in the early 1800s (Schroeder et al. 2004). Our data are consistent with this observation and provide support for the idea that shifts in sagebrush habitat distribution may have provided the greater sage-grouse an opportunity for range expansion, particularly in the northeastern part of their range.

The distribution of genetic variation shows a gradual shift across the range in both mitochondrial and nuclear data sets. An examination of the distribution of the most common mtDNA haplotypes demonstrates this phenomenon (Fig. 2). Haplotype A is the most widespread occurring in all but North Dakota, South Dakota, and Washington. Haplotype $X$ is found primarily in the western part of the range, while haplotypes $B$ and $C$ are found in the central and eastern part of the range. Haplotype EJ is found only in the northeastern part of the range in Alberta, Montana, North and South Dakota, and Wyoming. This pattern suggests localized gene flow with isolation by distance (i.e. movement among neighbouring populations yet not across the range).

Results from the NCA confirm this finding with seven clades characterized by restricted gene flow with isolation by distance $(1-5,1-13,1-20,2-1,2-8,3-4$, and 3-5). The lower order (more localized) clades (1-5, 1-13, 1-20) represented smaller portions of the range, yet the higher order (regional) clades (2-1, 2-8, 3-4, 3-5) represented most of the range. This suggests that restricted gene flow with isolation by distance is a range-wide phenomenon.

Analysis of our microsatellite data showed a similar pattern. The Mantel test showed a positive correlation between genetic distance and geographical distance suggesting an isolation-by-distance phenomenon (Fig. 6). In addition, the STRUCTURE analysis best grouped our data into 10 clusters (Fig. 5). All clusters were made up of populations geographically adjacent suggesting again patterns of localized gene flow and isolation by distance. The smaller, more fragmented populations on the periphery of the range (North Park, Middle Park, and Eagle in Colorado, Strawberry Valley and Wayne in Utah, Lyon/Mono in Nevada/California, and Douglass/Grant and Yakima in Washington) made up their own clusters suggesting lower amounts of gene flow in these areas.

Direct knowledge of the dispersal distances of the greater sage-grouse is limited. In one Colorado study, the respective median natal dispersal distances for 12 males and 12 females was $7.4 \mathrm{~km}$ and $8.8 \mathrm{~km}$, respectively (Dunn \& Braun 1985), distances more apt to be between neighbouring leks than between non-neighbouring populations. Some greater sage-grouse have been documented to move seasonally between summer and winter ranges. One study in Idaho estimated the average distance of these movements to be $13.1 \mathrm{~km}$ (Connelly et al. 1988). Our data are consistent with these studies suggesting that gene flow is likely limited to the movement of individuals between neighbouring populations and not likely the result of longdistance movements of individuals (across large portions of the range). This information is important because conservation efforts often consider translocations and augmentation of existing populations using animals from outside populations. Our data suggest linkages among neighbouring populations and differences among distant populations, raising the possibility that local adaptations may exist and that translocations should involve neighbouring populations rather than geographically distant populations.

Levels of genetic variation differed among populations (Tables 1 and 3). The highest level was found in Magic 
Valley in the mtDNA data set with 13 haplotypes per population and in Alberta in the microsatellite data set with an average of 7.14 alleles. In both mtDNA and micrsosatellite data sets, the least amount of genetic diversity (Tables 1 and 3) was in the two Washington populations, Yakima and Douglass/Grant, with one and three mtDNA haplotypes per population and an average of 3.29 and 3.14 microsatellite alleles per population, respectively.

Pairwise population $R_{\mathrm{ST}}$ tests also showed that Douglass/Grant and Yakima were significantly different from most populations $(27,32)$. Our NJ tree constructed using $R_{\mathrm{ST}}$ genetic distances (Fig. 4) showed that the two Washington populations were among the populations with the longest branches. The significant results of $R_{\mathrm{ST}}$ genetic distance comparisons are largely a reflection of the small number of alleles found in both populations.

Interestingly, the two Washington populations did not show signs of a recent population bottleneck as was found in Strawberry Valley, which had been documented to have had a severe population decline because of predation problems within the last 10 years (Utah Division of Wildlife, unpublished). The test for population bottlenecks, however, only detects recent bottlenecks on the order of 0.2-4.0 generations (Luikart \& Cornuet 1998). Population declines in Washington have been estimated to be at least $77 \%$ between 1960 and 1999 (Schroeder et al. 2000) suggesting that declines have been ongoing and significant for 40 years. The lack of genetic diversity in the Washington populations is not surprising given their small population size and isolation (Fig. 1) and the fact that they currently occupy only $8 \%$ of their historic range (Schroeder et al. 2000).

While the importance of maintaining substantial levels of genetic variation in a population has been the topic of considerable debate, most agree that genetic variation is relevant to the health and viability of populations and that it must be addressed and monitored in management plans (O'Brien \& Evermann 1988; Quattro \& Vrijenhoek 1989). Bouzat et al. (1998) and Westemeier et al. (1998) showed that fertility and hatching success of greater prairie chickens (Tympanuchus cupido) were reduced because of a bottleneck caused by habitat loss. The Washington populations of the greater sage-grouse, a close relative of the greater prairie chicken (both are members of Tetraoninae), have experienced similar isolation and reduction in population size resulting from loss of habitat and likely have the same potential for inbreeding effects. Further, genetically depauperate populations face enhanced susceptibility to parasitic agents or infectious disease such as West Nile virus, which has been shown to be a significant threat in the greater sage-grouse (Naugle et al. 2004). Management strategies for these populations have included the consideration of translocations from other populations since natural gene flow appears unlikely given the geographical isolation of these populations. Our genetic data suggest that any translocations or augmentations of the Washington populations should involve populations that are geographically close.

Using mtDNA sequence data, Benedict et al. (2003) previously noted that the Lyon/Mono population was genetically unique compared to other populations in California, Nevada, Oregon, and Washington. Our study substantiates their findings. While an additional 24 populations were added by our data set, the observation remains that Lyon/ Mono contains mostly novel haplotypes not found elsewhere across the range (Table 1). In fact, $93 \%$ of individuals from Lyon/Mono had novel haplotypes, while the average percentage of novel haplotypes among all other populations was 8.37. The genetic diversity present in Lyon/ Mono is comparable to (if not higher than) most other populations (11 haplotypes) suggesting that the differences are not caused by a genetic bottleneck or founder event.

This pattern was found as well in the nuclear data set. Pairwise population $R_{\mathrm{ST}}$ tests revealed that although there were many population pairs (194 of 990) that were significantly different, Lyon/Mono were significantly different from almost all other populations, reinforcing its genetic distinctiveness. Further, in the STRUCTURE analysis, the Lyon/Mono population was the only population forming its own cluster, which again supports the idea that this population is genetically distinct.

Benedict et al. (2003) suggested that the Lyon/Mono population has been isolated from other greater sage-grouse populations for thousands or perhaps tens of thousands of years, noting that most members of the population carry mitochondrial haplotypes that are not found elsewhere across the species range. In total, there are seven novel haplotypes of 10 found in the population, and 48 of the 54 individuals from Lyon/Mono carry one of those seven. The results of our NCA support the theory of Benedict et al. (2003) as one of our clades (1-3) representing the Lyon/Mono separation was characterized by allopatric fragmentation.

The concept of evolutionary significant units (ESUs) is increasingly used to set management goals for populations or groups of populations below the species level (e.g. Parker et al. 1999). Although the most appropriate definition of an ESU is currently being debated, the general concept is that a population that has diverged a significant amount genetically is evolutionarily independent from other populations. The debate involves the question of how much genetic differentiation is significant and the strictest definition incorporates the phylogenetic species concept. According to Moritz (1994), an ESU should 'be reciprocally monophyletic for mtDNA alleles and show significant divergence of allele frequencies at nuclear loci', whereas a management unit (MU) would require 'significant divergence of alleles at nuclear or mitochondrial loci'.

We have demonstrated that Lyon/Mono has significant divergent allele frequencies of nuclear microsatellite loci, 
but the mtDNA control region haplotypes are not reciprocally monophyletic despite most being newly arisen within this population. Although the Lyon/Mono population would be considered an MU as defined by Moritz (1994), it would not be considered an ESU. We believe, however, that Moritz's (1994) restrictive definition of ESU should not be applied without careful consideration of several aspects of the breeding biology of the species under consideration. In some cases, reciprocal monophyly may appear long after complete and irreversible isolating mechanisms are in place. Further, the time it takes to reach reciprocal monophyly in mitochondria is dependent upon such factors as effective population size of females, and population dynamics related to expanding vs. contracting populations. In a lek-breeding species such as the greater sagegrouse where a few males do most of the mating, sexual selection can act to influence morphological and behavioural traits at a rate much faster than can be tracked genetically. Also, as a consequence of that breeding biology, the nuclear genome may undergo more of a bottleneck relative to the maternally inherited mitochondrial genome than it would in most species. In essence, this would delay the time that it takes the mitochondrial genome to reach reciprocal monophyly relative to the amount of differentiation that is simultaneously occurring in the nuclear genome.

Surprisingly, the Lyon/Mono population is at least as divergent from other populations of the greater sagegrouse as Gunnison sage-grouse are from the greater sagegrouse by virtue of the large number of new haplotypes unique to that population. Gunnison sage-grouse were recognized as a new species of sage-grouse based on morphological, behavioural, and genetic data (Young et al. 2000). Preliminary comparisons of gross morphology and behaviour between Lyon/Mono and surrounding greater sage-grouse populations, however, have revealed little or no differences (S. E. Taylor, unpublished). This suggests that while Lyon/Mono may have been isolated for an amount of time similar to the isolation of Gunnison sage-grouse, they have not experienced a significant divergence in morphology or behavioural characteristics as has been documented in Gunnison sage-grouse (Young et al. 2000), which ultimately led to their reproductive isolation.

Because Lyon/Mono is so genetically different, however, they deserve special attention. They certainly qualify as a distinct population segment from a genetic stand point and may even warrant consideration as a new subspecies based on our genetic data. However, more comprehensive morphological and behavioural comparisons should be performed before a change in taxonomic status should be considered. Regardless of the label placed on this population, it should be managed separately and protected because of its genetic distinctiveness as it may contain genetic variation that may be important to the survival of the species over large timescales.
Our study documented the distribution of genetic variation across the entire range of the greater sage-grouse, determining that the Lyon/Mono population has a unique history of isolation distinct from all other populations and that two populations in Washington have low levels of genetic diversity. Further, we found that isolation by distance has left in imprint on greater sage-grouse gene pools, and that local adaptation is a realistic possibility for the species and should be considered in decisions involving translocations. This genetic data used in conjunction with large-scale demographic and habitat data will provide an integrated approach to conservation efforts for the greater sage-grouse.

\section{Acknowledgements}

We are grateful to the Western Association of Fish and Wildlife Agencies for providing major funding and coordinating collection of sample materials. We also thank the Colorado Division of Wildlife, the Nevada Division of Wildlife, and the Oregon Department of Fish and Wildlife, particularly C. E. Braun and S. Stiver, for providing the initial impetus and support for earlier sage-grouse genetic studies that led to this wider survey. Biologists in state wildlife agencies in California, Idaho, Montana, Nevada, North Dakota, South Dakota, Utah, Washington, and Wyoming were also helpful in selecting sample areas and facilitating tissue collection. C. L. Aldridge provided material from Alberta. We thank J. R. Young, N. W. Kahn, N. G. Benedict, and S. M. Pearson for their earlier work on this or related projects. We also thank H.-P. Liu, J. St. John, and three anonymous reviewers for helpful comments on earlier versions of this paper.

\section{References}

Benedict NG, Oyler-McCance SJ, Taylor SE, Braun CE, Quinn TW (2003) Evaluation of the eastern (Centrocercus urophasianus urophasianus) and western (Centrocercus urophasianus phaois) subspecies of sage-grouse using mitochondrial control-region sequence data. Conservation Genetics, 4, 301-310.

Bonnet E, Van de Peer Y (2002) zT: a software tool for simple and partial Mantel tests. Journal of Statistical Software, 7, 1-12.

Bouzat JL, Cheng HH, Lewin HA et al. (1998) Genetic evaluation of a demographic bottleneck in the greater prairie chicken. Conservation Biology, 12, 836-843.

Braun CE (1998) Sage-grouse declines in western North America: what are the problems? Proceedings of the Western Association of State Fish and Wildlife Agencies, 78, 139-156.

Clement M, Posada D, Crandall K (2000) TCs: a computer program to estimate gene genealogies. Molecular Ecology, 9, 16571660.

Connelly JW, Braun CE (1997) Long-term changes in sage grouse Centrocercus urophasianus populations in western North America. Wildlife Biology, 3, 229-234.

Connelly JW, Browers HW, Gates RJ (1988) Seasonal movements of sage grouse in southeastern Idaho. Journal of Wildlife Management, 52, 116-122.

Connelly JW, Schroeder MA, Sands AR, Braun CE (2000) Guidelines to manage sage grouse populations and their habits. Wildlife Society Bulletin, 28, 967-985. 
Cornuet JM, Luikart G (1997) Description and power analysis of two tests for detecting recent population bottlenecks from allele frequency data. Genetics, 144, 2001-2014.

Crandall KA, Templeton AR (1993) Empirical tests of some predictions from coalescent theory with applications to intraspecific phylogeny reconstruction. Genetics, 134, 959-969.

Crandall KA, Templeton AR, Sing CF (1994) Intraspecific phylogenetics, problems and solutions. In: Phylogeny Reconstruction (eds Scotland RWL, Siebert DJ, Williams DM), pp. 273-297. Clarendon, Oxford.

Dunn PO, Braun CE (1985) Natal dispersal and lek fidelity of sage grouse. Auk, 102, 621-627.

Ellsworth DL, Honeycutt RL, Silvy NJ (1996) Systematics of grouse and ptarmigan determined by nucleotide sequences of the mitochondrial cytochrome- $B$ gene. Auk, 113, 811-822.

Emslie SD (1985) The late Pleistocene (Rancholabrean) avifauna of Little Box Elder Cave, Wyoming. University of Wyoming, Contributions in Geology, 23, 63-82.

Emslie SD (2004) The early and middle Pleistocene avifauna from Porcupine Cave, Colorado. In: Early and Middle Pleistocene Biodiversity and Environmental Change: The Porcupine Cave Fauna from Colorado (ed. Barnowsky A), pp. 127-140. University of California Press, Berkeley.

Emslie SD, Heaton TH (1987) The late Pleistocene avifauna of Crystal Ball Cave, Utah. Journal of Arizona-Nevada Academy of Science, 21, 53-60.

Excoffier L, Smouse PE, Quattro JM (1992) Analysis of molecular variance inferred from metric distances among DNA haplotypes: application to human mitochondrial DNA restriction data. Genetics, 131, 479-491.

Felsenstein J (1989) PHYLIP (Phylogeny Inference Package), Version 3.2. Department of Genetics. University of Washington, Seattle.

Grayson DK (1976) A note on the prehistoric avifauna of the Lower Klamath basin. Auk, 93, 830-833.

Guo S, Thompson E (1992) Performing the exact test of HardyWeinberg proportions for multiple alleles. Biometrics, 48, 361-372.

Howard H (1952) The prehistoric avifauna of Smith Creek Cave, Nevada, with a description of a gigantic raptor. Bulletin of Southern California Academy of Sciences, 51, 50-54

Howard H, Miller AH (1933) Bird remains from cave deposits in New Mexico. Condor, 35, 15-18.

Hupp JW, Braun CE (1991) Geographical variation among sage-grouse populations in Colorado. Wilson Bulletin, 103, 255261.

Kahn NW, Braun CE, Young JR, Wood S, Mata DR, Quinn TW (1999) Molecular analysis of genetic variation among large- and small-bodied sage-grouse using mitochondrial control-region sequences. Auk, 116, 819-824.

Lucchini V, Hoglund J, Klaus S, Swenson J, Randi E (2001) Historical biogeography and a mitochondrial DNA phylogeny of grouse and ptarmigan. Molecular Phylogenetics and Evolution, 20, 149-162.

Luikart G, Cornuet JM (1998) Empirical evaluation of a test for identifying recently bottlenecked populations from allele frequency data. Conservation Biology, 12, 228-237.

Mantel N (1967) The detection of disease clustering and a generalized regression approach. Cancer Research, 27, 209-220.

McDonald HG, Anderson E (1975) A late Pleistocene vertebrate fauna from southeastern Idaho. Tebiwa, 18, 19-37.

Miller L (1963) Birds and Indians in the West. Bulletin of the Southern California Academy of Sciences, 62, 178-191.
Miller L (1965) Bird remains from an archaeological site in the Beaverhead Mountains of southeastern Idaho. Tebiwa, 8, 1720.

Moritz C (1994) Defining 'evolutionary significant units' for conservation. Trends in Ecology and Evolution, 9, 373-375.

Naugle DE, Aldridge CL, Walker BL et al. (2004) West Nile virus: pending crisis for greater sage-grouse. Ecology Letters, 7, 704-713.

O'Brien SJ, Evermann JF (1988) Interactive influence of infectious disease on genetic diversity of natural populations. Trends in Ecology and Evolution, 3, 254-259.

Oyler-McCance SJ, St. John J, Taylor SE, Quinn TW (2005) Population genetics of Gunnison sage-grouse: implications for management. Journal of Wildlife Management, in press.

Oyler-McCance SJ, Kahn NW, Burnham KP, Braun CE, Quinn TW (1999) A population genetic comparison of large- and smallbodied sage-grouse in Colorado using microsatellite and mitochondrial DNA markers. Molecular Ecology, 8, 1457-1465.

Page RDM (1996) TREEvIEW: an application to display phylogenetic trees on personal computers. Computer Applications in the Biosciences, 12, 357-358.

Parker KM, Sheffer RJ, Hedrick PW (1999) Molecular variation and evolutionarily significant units in the endangered Gila topminnow. Conservation Biology, 13, 108-116.

Posada D, Crandall KA, Templeton AR (2000) GEODIs: a program for the cladistic nested analysis of the geographical distribution of genetic haplotypes. Molecular Ecology, 9, 487-488.

Pritchard JK, Stephens M, Donnelly PJ (2000) Inference of population structure using multilocus genotype data. Genetics, 155, 945-959.

Quattro JM, Vrijenhoek RC (1989) Fitness differences among remnant populations of the endangered Sonoran topminnow. Science, 245, 976-978.

Raymond M, Rousset F (1995) GENEPOP (version 1.2): population genetics software for exact tests and ecumenicism. Journal of Heredity, 86, 248-249.

Schneider S, Roessli D, Excoffier L (2001) ARLEQUIN: a software for population genetics data analysis Version 2.001. Genetics and Biometry Laboratory, University of Geneva, Switzerland.

Schroeder MJ, Hays DW, Livingston MF et al. (2000) Changes in the distribution of sage-grouse in North America. Northwestern Naturalist, 81, 104-112.

Schroeder MJ, Aldridge CA, Apa AD et al. (2004) Distribution of sage-grouse in North America. Condor, 106, 363-376.

Shufeldt RW (1913) Review of the fossil fauna of the desert region of Oregon, with a description of additional material collected there. Bulletin of the American Museum of Natural History, 32, 123-178.

Slatkin M (1995) A measure of population subdivision based on microsatellite allele frequencies. Genetics, 139, 457-462.

Swofford DL (2003) PAUP*. Phylogenetic Analysis Using Parsimony ("and Other Methods), Version 4. Sinauer Associates, Sunderland, Massachusetts.

Templeton AR (1998) Nested clade analyses of phylogeographic data: testing hypotheses about gene flow and population history. Molecular Ecology, 7, 381-397.

Templeton AR (2004) Statistical phylogeography: methods of evaluating and minimizing inference errors. Molecular Ecology, 13, 789-809.

Templeton AR, Boerwinkle E, Sing CXF (1987) A cladistic analysis of phenotypic associations with haplotypes inferred from restriction endonuclease mapping. I. Basic theory and an analysis 
1310 S. J. OYLER-MCCANCE, S. E. TAYLOR and T. W. QUINN

of alcohol dehydrogenase activity in Drosophila. Genetics, 117, 343-361.

Templeton AR, Crandall KA, Sing CF (1992) A cladistic analysis of phenotypic associations with haplotypes inferred form restriction endonuclease mapping and DNA sequence data. III. Cladogram estimation. Genetics, 132, 619-633.

Westemeier RL, Brawn JD, Simpson SA et al. (1998) Tracking the long-term decline and recovery of an isolated population. Science, 282, 1695-1698.

Young JW, Braun CE, Oyler-McCance SJ, Hupp JW, Quinn TW (2000) A new species of sage-grouse (Phasianidae: Centrocercus) from southwestern Colorado. Wilson Bulletin, 112, 445-453.

Young JW, Hupp JW, Bradbury JW, Braun CE (1994) Phenotypic divergence of secondary sexual traits among sage-grouse
(Centrocercus urophasianus) populations. Animal Behaviour, 47, 135D-1362.

Portions of the data collected for this study comprised Sonja Taylor's MS thesis; she subsequently collected additional microsatellite data as a research associate. Sara Oyler-McCance (Conservation Geneticist with the US Geological Survey) and Tom Quinn (Associate Professor at the University of Denver) have been collaborating on genetic studies of sage-grouse for a number of years. They are co-directors of the Rocky Mountain Center for Molecular Conservation Genetics and Systematics at the University of Denver. 